\title{
Management of strawberry leaf blight disease caused by Phomopsis obscurans using silicate salts under field conditions
}

\author{
Farid Abd-El-Kareem, Ibrahim E. Elshahawy and Mahfouz M. M. Abd-Elgawad*
}

\begin{abstract}
Background: Due to the increased economic and social benefits of the strawberry crop yield in Egypt, more attention has been paid to control its pests and diseases. Leaf blight, caused by the fungus Phomopsis obscurans, is one of the important diseases of strawberry plants. Therefore, effect of silicon and potassium, sodium and calcium silicates, and a fungicide on Phomopsis leaf blight of strawberry under laboratory and field conditions was examined.

Results: Four concentrations, i.e., 0, 2, 4, and $6 \mathrm{~g} / \mathrm{l}$ of silicon as well as potassium, sodium and calcium silicates could significantly reduce the linear growth of tested fungus in the laboratory test where complete inhibition of linear growth was obtained with $6 \mathrm{~g} / \mathrm{l}$. The other concentrations showed less but favorable effects. The highest reduction of disease severity was obtained with potassium silicate and calcium silicate separately applied as soil treatment combined with foliar spray which reduced the disease incidence by 83.3 and $86.7 \%$, respectively. Other treatments showed significant $(P \leq 0.05)$ but less effect. The highest yield increase was obtained with potassium silicate and calcium silicate applied as soil treatment combined with foliar spray which increased fruit yield by 60 and $53.8 \%$, respectively. All tested treatments increased $(P \leq 0.05)$ the activities of the peroxidase, polyphenol oxidase, and chitinase enzymes.
\end{abstract}

Conclusions: All tested concentrations of silicon salts have suppressed the fungal growth and disease spread but with different degrees. The more the concentration, the better it suppresses the fungal growth and consequent effect on damaging strawberry plants. Potassium silicate and calcium silicate separately applied as soil treatment combined with foliar spray were the best in reducing the disease incidence and increasing crop yield. Potential implications of silicate salts on enhancing activities of the tested enzymes reflected their role in protection against such a plant disease.

Keywords: Enzyme activity, Leaf blight, Silicate salts, Strawberry, Yield loss

\section{Background}

In Egypt, strawberry (Fragaria $\times$ ananassa Duchesne) has become increasingly important crop in recent years due to its economic and social benefits (El-Shemy et al. 2013). With the ongoing nature of the economic crisis, the socio-economic importance of cultivating strawberry is enhanced because, in addition to its local consumption as fresh fruit and juice, strawberry provides a significant source of foreign currency. Its cultivation and related activities alleviate the problem of unemployment. However, growing strawberry may be attacked by numerous pathogens and pests which render its crop yield to considerable losses. In

\footnotetext{
* Correspondence: mahfouzian2000@yahoo.com

Plant Pathology Department, National Research Centre, Dokki, Giza 12622, Egypt
}

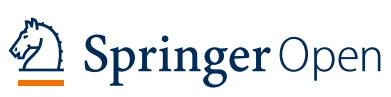

(c) The Author(s). 2019 Open Access This article is distributed under the terms of the Creative Commons Attribution 4.0 International License (http://creativecommons.org/licenses/by/4.0/), which permits unrestricted use, distribution, and reproduction in any medium, provided you give appropriate credit to the original author(s) and the source, provide a link to the Creative Commons license, and indicate if changes were made.

this respect, leaf blight, caused by the fungus Phomopsis obscurans [(Ellis \& Everh.) B. Sutton] is an important summertime disease because so few varieties have adequate resistance to it (Louws 2007; Ellis and Nita 2018; Louws and Ridge 2014). Once considered to be a disease only of older or weakened leaves, leaf blight has become an important disease, aggressively attacking leaves of any age. Lesions begin as circular to elliptical, purple spots that can appear identical to those of common leaf spot or leaf scorch. The purple spots develop dark brown centers as they enlarge. Some infected leaves display large V-shaped lesions, with the widest part at the leaf edge. If the spots become numerous, large areas of the leaf become purple or red, and the leaf may die. The fungus can also cause dark lesions on stems and berry caps. On berries, infection can cause a soft, light pink lesion that develops a tough, 
tan-colored center. The disease can weaken strawberry plants through the destruction of foliage, which results in considerably reduced yields (Elmer 1990; Louws 2007; Louws and Ridge 2014; Ellis and Nita 2018).

Silicon (Si) has been described as a non-essential element of plant nutrients, but it can play a vital role to improve disease resistance in plants and has important potential in the plant growth and development (Datnoff et al. 2001). Foliarapplied $\mathrm{Si}$ was found to effectively control powdery mildew in cucumber, muskmelon, and zucchini squash (Elsharkawy et al. 2015). In those experiments, however, inoculation was carried out directly on the Si-sprayed leaves, and the effect of Si on the suppression of subsequent disease was evaluated only in the Si-sprayed, inoculated leaves without taking the whole plant. Potassium silicate is the main source of soluble potassium and silicon. In general, plants require silica to resist against biotic and abiotic stress (Ma 2004). Silicon added to the soil as nutrient solution exhibited enhancement in plant growth, yield, and resistance to various diseases and insects as well as reduced the harmful effects of mineral toxicities (Bélanger et al. 1995). Elsharkawy et al. (2015) stressed the potential impact of soluble $\mathrm{Si}$ for increasing resistance to fungal diseases such as powdery mildew and root rot.

The aim of this study is to evaluate the effect of silicon as well as potassium, sodium, and calcium silicates against Phomopsis leaf blight of strawberry plants in the laboratory and under field conditions.

\section{Methods}

\section{Pathogen}

Pathogenic isolate of Phomopsis obscurans and the causal agent of leaf blight disease of strawberry plants were kindly provided by Plant Pathology Department, National Research Centre, Giza, Egypt.

\section{Plant materials}

Six-month-old seedlings of strawberry cv. Festival were obtained from Vegetable Crops Research Department, Agricultural Research Centre, Giza, Egypt.

\section{Laboratory tests}

Four concentrations i.e. 0, 2, 4 and $6 \mathrm{~g} / \mathrm{l}$ of silicon as well as potassium, sodium and calcium silicates were tested as separate treatments to study their effect on linear growth of Phomopsis obscurans under laboratory conditions. These concentrations were added individually to previously sterilized potato dextrose agar (PDA) before its solidification and then poured in sterile Petri-plates. After solidification, the plates were inoculated with fungal disc $(6-\mathrm{mm})$ in the center of the plate and incubated at $25 \pm 1{ }^{\circ} \mathrm{C}$. Five plates were replicated for each particular treatment of each concentration and five plates served as control for each treatment. Linear growth was recorded after 7 days of incubation, and reduction in linear growth was estimated.

\section{Field experiment}

Field experiment was carried out at Tukh district, El-Qaluobia governorate, Egypt. At the Middle of November 2017, strawberry seedlings were transplanted into a field with loamy clay, well-drained soil with history infection with Phomopsis obscurans; the casual of leaf blight disease. The experimental layout was a randomized complete block design with three replicates (plots) for each treatment. Each plot $(4 \times 8 \mathrm{~m})$ comprised 8 rows ( 32 plants/row). All agricultural practices were carried out as recommended (El-Shemy et al. 2013). The abovementioned treatments were tested but at concentration of only $6 \mathrm{~g} / \mathrm{l}$ to study their effect on leaf blight disease of strawberry. Every 15 days for 4 months, each treatment was applied as soil treatment alone and as soil treatment combined with foliar spray. For soil treatment, soil of each plant received $40 \mathrm{ml}$ per treatment. For soil treatment combined with foliar spray, soil and plant received $80 \mathrm{ml}$ per treatment as $50-50$.

\section{Disease and yield assessment}

Phomopsis leaf blight severity was assessed according to disease scale provided by Louws (2007). This scale was as follows: $0=$ no lesion, $1=20 \%$ or less, $2=21-40 \%, 3=41-$ $60 \%, 4=61-80 \%, 5=81-100 \%$ of leaf infected area. Disease was recorded 100 days after transplanting. On the other hand, accumulated yield of strawberry (Ton/feddan) under field conditions was estimated at season-end in April 2018.

\section{Determination of enzyme activities Extraction of enzymes}

Plant leaves (g) were taken after 120 days of planting, then homogenized with $0.1 \mathrm{M}$ sodium phosphate buffer (pH 7.1) at the rate of $1 / 3 w / v$ (Goldschmidt et al. 1968). The homogenate was centrifuged at $3000 \mathrm{rpm}$ for $15 \mathrm{~min}$. The supernatant was used to determine activities of the following enzymes.

\section{Peroxidase assay}

Peroxidase activity was measured by incubation $0.1 \mathrm{ml}$ of enzyme extract with $4 \mathrm{ml}$ of guaicol solution for $1 \mathrm{~min}$ at $25^{\circ} \mathrm{C}$ and absorbance at $470 \mathrm{~nm}$. The guaicol solution consisted of $3 \mathrm{ml}$ of $0.05 \mathrm{M}$ potassium phosphate, $\mathrm{pH} 7$, $0.5 \mathrm{ml}$ of $2 \%$ guaicol, and $0.5 \mathrm{ml}$ of $0.3 \% \mathrm{H}_{2} \mathrm{O}_{2}$ (Abeles et al. 1971). Peroxidase activity was expressed as the increase in absorbance at $470 \mathrm{~nm} / \mathrm{gram}$ fresh weight/1 $\mathrm{min}$ using spectrophotometer (Spectronic 20-D).

\section{Polyphenol oxidase assay}

For polyphenol oxidase determination, a calorimetric procedure was used (Matta and Diamond 1963). The reaction mixture contained $1 \mathrm{ml}$ of crude enzyme extract, 1 $\mathrm{ml}$ of $0.2 \mathrm{M}$ sodium phosphate buffer at $\mathrm{pH} 7.01$, and 1 $\mathrm{ml}$ of $10 \mathrm{M}$ catechol brought to final volume of $6 \mathrm{ml}$ with distilled water. The activity of polyphenol oxidase 
was expressed as the change in the absorbance of the mixture every $0.5 \mathrm{~min}$ period at $495 \mathrm{~nm}$.

\section{Chitinase assay}

The substrate colloidal chitin was prepared from chitin powder according to the method described by Ried and Ogryd-Ziak (1981). Determination of chitinase activity was carried out according to the method of Monreal and Reese (1969). One milliliter of $1 \%$ colloidal chitin in $0.05 \mathrm{M}$ citrate phosphate buffer ( $\mathrm{pH} 6.6)$ in test tubes, and $1 \mathrm{ml}$ of enzyme extract was added and mixed by shaking. Tubes were kept in a water bath at $37^{\circ} \mathrm{C}$ for $60 \mathrm{~min}$, then cooled and centrifuged before assaying. Reducing sugar was determined in $1 \mathrm{ml}$ of the supernatant by dinitrosalicylic acid. The reaction was stopped by heating the tubes for $5 \mathrm{~min}$ at $100^{\circ} \mathrm{C}$. The tubes were cooled, and $3 \mathrm{ml}$ of distilled water was added before assay. Optical density was determined at $540 \mathrm{~nm}$ using Spectrophotometer (Spectronic 20-D). Chitinase activity was expressed as $\mathrm{mM} \mathrm{N}$-acetylglucose amine equivalent released/gram fresh weight tissue/60 min.

\section{Statistical analysis}

Tukey test for multiple comparisons among means was utilized (Neler et al. 1985).

\section{Results}

\section{Laboratory test}

Results in Table 1 show the effect of different concentrations of silicon and its salts which could significantly reduce the linear growth of tested fungus. Complete inhibition of linear growth was obtained with $6 \mathrm{~g} / \mathrm{l}$. Meanwhile, moderate

Table 1 Effect of silicon and potassium, sodium, and calcium silicates on linear growth of Phomopsis obscurans under laboratory conditions

\begin{tabular}{|c|c|c|c|}
\hline \multirow[t]{2}{*}{ Treatment } & \multirow{2}{*}{$\begin{array}{l}\text { Conc. } g \\
\text { or } \mathrm{mL} / \mathrm{L} \text {. }\end{array}$} & \multicolumn{2}{|l|}{ Phomopsis obscurans } \\
\hline & & Linear growth $(\mathrm{mm})$ & Reduction \% \\
\hline \multirow[t]{3}{*}{ Silicon } & 2 & $42.0 \mathrm{bc}$ & 53.3 \\
\hline & 4 & $22.0 \mathrm{c}$ & 75.6 \\
\hline & 6 & 00.0 e & 100 \\
\hline \multirow[t]{3}{*}{ Potassium silicate } & 2 & $38.0 \mathrm{~b}$ & 57.8 \\
\hline & 4 & $15.0 \mathrm{~d}$ & 83.3 \\
\hline & 6 & $00.0 \mathrm{e}$ & 100 \\
\hline \multirow[t]{3}{*}{ Sodium silicate } & 2 & $40.0 \mathrm{~b}$ & 55.6 \\
\hline & 4 & $19.0 \mathrm{~cd}$ & 78.9 \\
\hline & 6 & $00.0 \mathrm{e}$ & 100 \\
\hline \multirow[t]{3}{*}{ Calcium silicate } & 2 & $43.0 \mathrm{~b}$ & 52.2 \\
\hline & 4 & $25.0 \mathrm{C}$ & 72.2 \\
\hline & 6 & 00.0e & 100 \\
\hline Control & 0 & $90.0 \mathrm{a}$ & 0.0 \\
\hline
\end{tabular}

Figures with the same letters are not significantly different $(P \leq 0.05)$ using Tukey's test effect was obtained with concentration at $4 \mathrm{~g} / \mathrm{l}$ which reduced the linear growth more than $72.2 \%$. Other concentrations were less effective.

\section{Field experiment}

Results in Table 2 reveal that all tested concentrations of silicon and its salts significantly reduced the disease incidence. The highest reduction of disease severity was obtained with potassium silicate and calcium silicate applied as soil treatment combined with foliar spray which reduced the disease severity by 83.3 and $86.7 \%$, respectively. This was followed by potassium silicate and calcium silicate applied as soil treatment which reduced the disease severity $73.3 \%$. Meanwhile, other treatments showed moderate effect.

Results in Table 3 indicate that all tested concentrations significantly increased strawberry yield. The highest increase was obtained with potassium silicate and calcium silicate applied as soil treatment + foliar spray which increased strawberry yield by 60 and $53.8 \%$, respectively. Meanwhile, other treatments showed moderate effect.

\section{Effect on enzyme activities}

Results in Table 4 show that all tested treatments significantly increased the enzyme activities. The highest increase was obtained with potassium silicate and calcium silicate applied as soil treatment + foliar spray which increased peroxidase, polyphenol oxidase, and chitinase by 200 and 175 , 250 and 233.3, and 225 and 200\%, respectively. Meanwhile, other treatments showed moderate effect.

\section{Discussions}

Leaf blight, caused by the fungus Phomopsis obscurans, is an important disease of strawberry plants. The disease can weaken strawberry plants through the destruction of foliage which results in reduced yields. High temperature

Table 2 Effect of silicon and potassium, sodium and calcium silicates, and a fungicide on Phomopsis leaf blight disease of strawberry plants under field conditions

\begin{tabular}{llll}
\hline Treatment & Application & Phomopsis leaf blight & Reduction \\
\hline Silicon & Soil & $1.3 \mathrm{c}$ & 56.7 \\
& Soil+ foliar & $1.1 \mathrm{~cd}$ & 63.3 \\
Potassium silicate & Soil & $0.8 \mathrm{de}$ & 73.3 \\
& Soil+ foliar & $0.5 \mathrm{e}$ & 83.3 \\
Sodium silicate & Soil & $1.9 \mathrm{~b}$ & 36.7 \\
& Soil+ foliar & $1.5 \mathrm{C}$ & 50.0 \\
Calcium silicate & Soil & $0.8 \mathrm{~d}$ & 73.3 \\
& Soil+ foliar & $0.4 \mathrm{e}$ & 86.7 \\
Amstar (fungicide) $1 \mathrm{ml} / /$ foliar & $0.6 \mathrm{de}$ & 80.0 \\
Control & & $3.0 \mathrm{a}$ & 0.0 \\
\hline
\end{tabular}

Figures with the same letters are not significantly different $(P \leq 0.05)$ using Tukey's test 
Table 3 Effect of silicon and potassium, sodium and calcium silicates, and a fungicide on strawberry yield under field conditions

\begin{tabular}{llll}
\hline Treatment & Application & Yield (tons/feddan) & Increase \% \\
\hline Silicon & Soil & $7.4 \mathrm{~d}$ & 13.8 \\
& Soil+ foliar & $8.5 \mathrm{~b}$ & 30.8 \\
Potassium silicate & Soil & $8.0 \mathrm{bc}$ & 23.1 \\
& Soil+ foliar & $10.4 \mathrm{a}$ & 60 \\
Sodium silicate & Soil & 7.2 & 10.8 \\
& Soil+ foliar & $7.4 \mathrm{~d}$ & 13.8 \\
Calcium silicate & Soil & $7.9 \mathrm{c}$ & 21.5 \\
& Soil+ foliar & $10.0 \mathrm{a}$ & 53.8 \\
Amstar (fungicide) $1 \mathrm{ml} / \mathrm{I}$ & foliar & $7.8 \mathrm{c}$ & 20.0 \\
Control & & $6.5 \mathrm{e}$ & 0.0 \\
\hline
\end{tabular}

Figures with the same letters are not significantly different $(P \leq 0.05)$ using Tukey's test

and inoculum density with enhanced moisture and immature host tissue are major factors favorable for the growth and development of this fungus (Eschenaur and Milholland 1989). Thus, in years with such favorable factors, leaf blight can ultimately lead to the death of the strawberry plants. On the other hand, results herein indicated that all tested concentrations significantly reduced the linear growth of $P$. obscurans but with different degrees as in Table 1. Complete inhibition of linear growth was obtained with the applied highest dose. Under field conditions, the highest reduction of disease severity was obtained with potassium silicate and calcium silicate separately, each applied as soil treatment combined with foliar spray. They reduced the disease incidence by 83.3 and $86.7 \%$, respectively (Table 2).

An integrated disease management is the most effective way of avoiding P. obscurans infection (Elmer 1990; Louws 2007; Ellis and Nita 2018). Admittedly, preventive measures are major approaches for the disease management wherein agricultural practices rank high among the disease control measures. In this vein, the use of certified disease-free plants, clearing the field of old plant debris from previous plants because overwintered fungus is commonly found in these debris and can easily lead to a new fungal inoculum, selecting a field with excellent soil drainage and good air circulation by allowing enough space between plants, applying overhead irrigation in the early morning to speed up the drying of leaves during the day to prevent the growth of pathogens, and control of weeds which may favor an environment for pathogen growth.

Bekker et al. (2006) tested also soluble potassium silicate against Phytophthora cinnamomi, Sclerotinia sclerotiorum, Pythium sp., Mucor pusillus, Drechslera sp., Fusarium oxysporum, F. solani, Alternaria solani, Colletotrichum coccodes, Verticillium theobromae, Curvularia lunata, and Stemphylium herbarum. They found that inhibition of mycelial growth was dose-related with $100 \%$ inhibition at $80 \mathrm{ml}(\mathrm{pH} \mathrm{11.7)}$ and $40 \mathrm{ml}(\mathrm{pH} 11.5)$ soluble potassium silicate per liter of agar, for all fungi tested with the exception of Drechslera sp. and F. oxysporum at $40 \mathrm{ml}$ in one experiment. Both S. sclerotiorum and P. cinnamomi were completely inhibited at all soluble potassium silicate concentrations between 5 and $80 \mathrm{ml} / 1$ agar, while the other fungi were only partially inhibited at potassium silicate concentrations of 5, 10, and $20 \mathrm{ml} / 1$ agar. Percentage inhibition was positively correlated with dosage. Bekker et al. (2009) demonstrated in vitro inhibition of mycelial growth of phytopathogenic fungi grown on potassium silicate-amended media. In the present study, the respective effects on fungal growth due to the $\mathrm{pH}$ adopted for the growth medium with increased concentrations of potassium silicate and potassium silicate were investigated. Thus, to assess the effect of $\mathrm{pH}$ on mycelial growth, PDA was adjusted to $\mathrm{pH}$ (10.3-11.7) similar to those associated with potassium silicate concentrations $(20-80 \mathrm{ml} / \mathrm{l}$ potassium

Table 4 Effect of silicon and potassium, sodium and calcium silicates, and a fungicide on enzyme activities of strawberry plants under field conditions

\begin{tabular}{|c|c|c|c|c|c|c|c|}
\hline \multirow[t]{3}{*}{ Treatment } & \multirow[t]{3}{*}{ Application } & \multicolumn{6}{|c|}{ Enzyme activities } \\
\hline & & \multicolumn{2}{|c|}{ Peroxidase } & \multicolumn{2}{|c|}{ Polyphenol oxidase } & \multicolumn{2}{|l|}{ Chitinase } \\
\hline & & Activity & Increase \% & Activity & Increase $\%$ & Activity & Increase $\%$ \\
\hline \multirow[t]{2}{*}{ Silicon } & Soil & 1.5 & 87.5 & 1.4 & 133.0 & 4.5 & 125.0 \\
\hline & Soil+ foliar & 1.8 & 125.0 & 1.4 & 133.0 & 4.5 & 125.0 \\
\hline \multirow[t]{2}{*}{ Potassium silicate } & Soil & 2.0 & 150.0 & 1.8 & 200.0 & 5.0 & 150.0 \\
\hline & Soil+ foliar & 2.4 & 200.0 & 2.1 & 250.0 & 6.5 & 225.0 \\
\hline \multirow[t]{2}{*}{ Sodium silicate } & Soil & 1.5 & 87.5 & 1.5 & 150.0 & 4.5 & 125.0 \\
\hline & Soil+ foliar & 1.8 & 125.0 & 1.7 & 183.3 & 5.5 & 175.0 \\
\hline \multirow[t]{2}{*}{ Calcium silicate } & Soil & 2.0 & 150.0 & 1.5 & 150.0 & 5.5 & 175.0 \\
\hline & Soil+ foliar & 2.2 & 175.0 & 2.0 & 233.3 & 6.0 & 200.0 \\
\hline Amstar (fungicide) $1 \mathrm{ml} / \mathrm{l}$ & Foliar & 1.5 & 87.5 & 1.4 & 133.0 & 4.5 & 125.0 \\
\hline Control & Untreated & 0.8 & & 0.6 & 0.0 & 2.0 & 0.0 \\
\hline
\end{tabular}


silicate and $20.7 \%$ silicon dioxide) using $\mathrm{KOH}$. Inhibition of mycelial growth was dose-related with $100 \%$ inhibition at concentrations $>40 \mathrm{ml}$ ( $\mathrm{pH} 11.5)$ soluble potassium silicate per liter of agar. Meanwhile, all such treatments which controlled the fungal disease(s) have certainly increased strawberry yield.

Nada et al. (2014) stated that potassium silicate was the most effective treatment among other silicon sources tested, i.e., calcium silicate and sodium silicate in reducing damping-off incidence and in improving plant growth parameters as well as seed yield. Kanto et al. (2006) reported that both potassium silicate and calcium silicate suppressed Fusarium wilt of cucumber for 3 years more than sodium silicate. They tested liquid potassium silicate as soil drench to control the powdery mildew of strawberry in the soil and found that the soluble potassium silicate suppressed the powdery mildew disease more efficiently as a protective control than as a control to diminish initial incidence. Also, they measured silicate-treated leaves and found that leaves treated by silicate were harder than control leaves. Moreover, Jayawardana et al. (2014) reported that the root and the foliar application of soluble silicon as potassium silicate caused decrease in disease incidence and increase in plant growth and fruit quality parameters. Weerahewa and David (2015) tested tomato cultivars "Thilina" and "Maheshi" by soil application of silicon at 0,50 , and $100 \mathrm{mg} / \mathrm{l}$ during the growth stage, flowering stage, and both growth and flowering stages to control anthracnose. They reported a reduction of lesions by $80 \%$ in "Maheshi" and $87 \%$ in "Thilina," respectively. In this vein, Cherif and Belanger (1992) evaluated amendment with potassium silicate as means to control Pythium ultimum infection on cucumber and reported that supplying the solutions with 100 or $200 \mathrm{ppm}$ of potassium silicate significantly reduced plant mortality, root decay, and yield losses attributed to the infection. Furthermore, Rodrigues et al. $(2003,2010)$ suggested that potassium silicate sprays could reduce the intensity of angular leaf spot on beans. Liang et al. (2005) noticed that silicon can prevent pathogen penetration into host tissues. Reduction in disease incidence in plants treated with silicon sources under field conditions is not probably due to the fungi-static effects of silicon, but silicon could act as physical barrier against pathogen penetration or it can be used as inducer for defense response in plants (Shen et al. 2010).

Cherif and Belanger (1992) found that treating cucumber roots with soluble silicon resulted in an increase in the activities of peroxidase and polyphenol oxidase in addition to stimulated accumulation of polymerized phenolic compounds. Numerous explanations of the silicon role to suppress onion white rot disease like the emerging role of it as a biologically active element capable of improving the natural defense system of the plant. Silicon-treated plants exhibited increased activity of peroxidases, chitinases, polyphenol oxidases, and flavonoid phytoalexins, which play an important role in the resistance of the plant to fungal pathogens (Fawe et al. 1998). Furthermore, the higher production of glycosylated phenolics, antimicrobial products such as diterpenoid phytoalexins and a prolinerich protein in the silicon-treated plants indicated that these products can have a role in the protection effects induced by silicon against plant diseases (Rodrigues et al. 2003). The bioactivity of silicon as a regulator of plant defense mechanisms may be explained through the biochemical properties. Silicon bind with hydroxyl groups of proteins which involved in signal transduction. Also, silicon may interfere with cationic co-factors of the enzymes which influence pathogenesis-related events.

Basically, plant reactions to attack plant pathogens are very complex, and involve the activation of set of genes, encoding different proteins. Pathogen attack can induce biochemical and physiological changes in plants, such as physical strengthening of the cell wall through lignification, suberization, and callose deposition by producing phenolic compounds, phytoalexins, and pathogenesis-related (PR) proteins which subsequently prevent various pathogen invasions (Ebrahim et al. 2011). These processes go generally in parallel to our results herein which indicated that all tested treatments significantly increased the enzyme activities. The highest increase was obtained with potassium silicate and calcium silicate applied as soil treatment + foliar spray which increased the activity of peroxidase, polyphenol oxidase, and chitinase enzymes by 200 and 175, 250 and 233.3, and 225 and $200 \%$, respectively. Other treatments showed moderate effect. In this respect, Ryals et al. (1996) reported that production and accumulation of pathogenesis-related proteins in plants in response to invading pathogen and/or stress situation is very important. Phytoalexins are mainly produced by healthy cells adjacent to localized damaged and necrotic cells, but PR proteins accumulate locally in the infected and surrounding tissues, and also in remote uninfected tissues. Production of PR proteins in the uninfected parts of plants can prevent the affected plants from further infection. Most PR proteins in the plant species are acid-soluble, low molecular weight, and protease-resistant proteins. Currently PR proteins include families distinguished according to their properties and functions such as $\beta$-1,3-glucanases, chitinases, thaumatin-like proteins, peroxidases, ribosome-inactivating proteins, defenses, thionins, nonspecific lipid transfer proteins, oxalate oxidase, and oxalate-oxidase-like proteins (Ebrahim et al. 2011).

\section{Conclusion}

In Egypt, strawberry has become increasingly important crop in recent years due to its economic and social benefits. Yet, such an expansion in strawberry cultivation entails the danger of considerable yield losses caused by many pests and diseases. Leaf blight of strawberry, caused by the fungus Phomopsis obscurans, is an important summertime 
disease because so few varieties have adequate resistance to it. Despite all preventive control measures of the disease, there are many strawberry fields that have inevitable $P$. obscurans-infection annually with this disease, leading to considerable losses in the crop yield. So, additional control measures are desperately needed. Our results revealed that all concentrations of silicate salts tested herein significantly reduced the leaf blight disease under field conditions. The highest reduction of disease severity was obtained with potassium silicate and calcium silicate applied separately as soil treatment combined with foliar spray which reduced the disease incidence by 83.3 and $86.7 \%$, respectively.

As for strawberry yield, the highest increase was obtained with potassium silicate and calcium silicate applied as soil treatment + foliar spray which increased strawberry yield by 60 and 53.8\%, respectively. The high activities of peroxidase, polyphenol oxidase, and chitinase induced by silicate salts herein indicated that these enzymes can have a role in the protection effects induced by silicon against such a plant disease.

\section{Acknowledgements}

This study was supported in part by the US-Egypt Project cycle 17 (no. 172) entitled 'Preparing and evaluating IPM tactics for increasing strawberry and citrus production'.

\section{Funding}

Financial support made by US-Egypt Project fund for Project cycle 17 (no. 172) and National Research Centre, Egypt, is gratefully acknowledged.

\section{Availability of data and materials}

The datasets used and/or analyzed during the current study are available from the corresponding author on reasonable request.

\section{Authors' contributions}

All authors participated in the development and implementation of the research plan and subsequently written it. All authors read and approved the final manuscript.

\section{Ethics approval and consent to participate}

Not applicable

\section{Consent for publication}

Not applicable

\section{Competing interests}

The authors declare that they have no competing interests.

\section{Publisher's Note}

Springer Nature remains neutral with regard to jurisdictional claims in published maps and institutional affiliations.

Received: 28 November 2018 Accepted: 14 December 2018

Published online: 05 January 2019

\section{References}

Abeles FB, Bosshart RP, Forrence LE, Habig WH (1971) Preparation and purification of glucanase and chitinase from bean leaves. PI Physiol 47:129-134

Bekker TF, Kaiser C, Labuschagne N (2009) The antifungal activity of potassium silicate and the role of $\mathrm{pH}$ against selected plant pathogenic fungi in vitro. South Afr J PI Soil 26:1. https://doi.org/10.1080/02571862.2009.10639934

Bekker TF, Kaiser C, Merwe R, Labuschagne N (2006) In-vitro inhibition of mycelial growth of several phytopathogenic fungi by soluble potassium silicate. South Afr J PI Soil 23:224-232
Bélanger RR, Bowen PA, Ehret DL, Menzies JG (1995) Soluble silicon: its role in crop and disease management of greenhouse crops. PI Dis 79:329-336

Cherif M, Belanger RR (1992) Use of potassium silicate amendments in recirculating nutrient solutions to suppress Pythium ultimum on long English cucumber. Pl Dis 79:1008-1011

Datnoff LE, Synder GH, Korndorfer GH (2001) Silicon in agriculture. Elsevier Science, New York

Ebrahim S, Usha K, Singh B (2011) Pathogenesis related (PR) proteins in plant defense mechanism. Res Tech Adv 6:1043-1054

Ellis MA, Nita M (2018) Phomopsis leaf blight and fruit rot of strawberry. Agric Nat Resourc: On line. https://ohioline.osu.edu/factsheet/plpath-fru-18. Accessed 27 Nov 2018

Elmer WH (1990) Recent outbreak of Phomopsis leaf blight, caused by Phomopsis obscurans, on strawberny petioles and stolons in Connecticut. PI Dis 74:331-334

Elsharkawy MM, Hase T, Shimizu M, Hyakumachi M (2015) Suppressive effects of a polymer sodium silicate solution on powdery mildew and root rot diseases of miniature rose. Afr J Biotech 14(42):2917-2927

El-Shemy AA, Khafagy YS, Al-Genteery AMM (2013) Cultivation and production of strawberry. Cairo: Tech issue no. 9/2013, General Directorate of Agricultural Culture. Egypt Minist Agric (in Arabic)

Eschenaur BC, Milholland RD (1989) Factors influencing the growth of Phomopsis obscurans and disease development on strawberry leaf and runner tissue. PI Dis 73(10):814-819

Fawe A, Abou-Zaid M, Menzies JG, Bélanger RR (1998) Silicon mediated accumulation of flavonoid phytoalexins in cucumber. Phytopath 88:396-401

Goldschmidt EE, Goren R, Monselise SP (1968) The indol acetic acid oxidase system of citrus roots. Planta 72:213-222

Jayawardana HARK, Weerahewa HLD, Saparamadu MDJS (2014) Effect of root or foliar application of soluble silicon on plant growth, fruit quality and anthracnose development of capsicum. Trop Agric Res 26(1):74-81

Kanto T, Miyoshi A, Ogawa T, Maekawa K, Aino M (2006) Suppressive effect of liquid potassium silicate on powdery mildew of strawberry in soil. J Gener PI Path 72(3):137-142

Liang YC, Sun WC, Si J, Romheld V (2005) Effects of foliar- and root-applied silicon on the enhancement of induced resistance to powdery mildew in Cucumis sativus. PI Path 54:678-685

Louws F, Ridge G (2014) Phomopsis leaf blight of strawberry. North Carolina State Extension Publications, USA

Louws JF (2007) Detection and management of anthracnose and Phomopsis blight in strawberry production in the Southeast. North Carolina State University, Progress report, grant code: SRSFC 2007-05

Ma JF (2004) Role of silicon in enhancing the resistance of plants to biotic and abiotic stresses. Soil Sci PI Nutr 50:11-18

Matta A, Diamond AE (1963) Symptoms of Fusarium wilt in relation to quantity of Fusarium and enzyme activity in tomato stems. PI Path 53:574-578

Monreal J, Reese ET (1969) The chitinase of Serratia marcescens. Can J Microbiol 15:689-696

Nada MGA, Doaa A, Imarah A, Halawa AEA (2014) Efficiency of some silicon sources for controlling damping-off of coriander (Coriandrum sativum $\mathrm{L}$.) in Egypt. Egypt J Phytopathol 42(2):73-90

Neler J, Wassermann W, Kutner MH (1985) Applied linear statistical models. Regression, analysis of variance and experimental design, 2nd edn. Irwin Inc, Homewood Illionois

Ried JD, Ogryd-Ziak DM (1981) Chitinase over producing mutant of Servatia marcescens. Appl Environ Microbiol 41:664-669

Rodrigues FA, Benhamou N, Datnoff JB, Jones B, Bélanger RR (2003) Ultrastructural and cytochemical aspects of silicon-mediated rice blast resistance. Phytopath 93:535-546

Rodrigues FA, Duarte HSS, Rezende DC, Wordell JA, Filho GH, Korndörfer K, Zambolim KL (2010) Foliar spray of potassium silicate on the control of angular leaf spot on beans. J PI Nutr 33(4):2082-2093

Ryals JA, Neuenschwander UH, Willits MG, Molina A, Steiner HY, Hunt MD (1996) Systemic acquired resistance. PI Cell 8:1809-1819

Shen GH, Xue QH, Tang M, Chen Q, Wang LN, Duan CM, Xue L, Zhoo J (2010) Inhibitory effects of potassium silicate of five soil-borne phytopathogenic fungi in vitro. J PI Dis Prot 117(4):180-184

Weerahewa D, David D (2015) Effect of silicon and potassium on tomato anthracnose and on the postharvest quality of tomato fruit (Lycopersicon esculentum Mill.). J Nat Sci Foundation Sri Lanka 43(3):271-278 